\title{
Social Significance and Requirements of Inclusive Education
}

\author{
Esmira Tahirova, SEVInj Guliyeva, Arkinaz Rasulzada \\ ADA High School St. Ahmadbay Aghaoglu 11, \\ Baku, 1008 AZERBAIJAN
}

\begin{abstract}
The aim of our research is to explore the ways to ensure the active participation of every child in the educational process, regardless of inclusive learning abilities and educational needs. In order to achieve the set goal, the following tasks are planned to be performed: Analysis of gaps in educational opportunities of the children with disabilities and identification of the ways of solution; Investigation of the ways of provision of support by healthy students to the learning process by working together with the students with disabilities; In our research, we will try to find answers to the following questions. What steps are needed to be made for making learning accessible and comfortable and most importantly to formalize social and life skills? How important is it to change teaching methods for all children to develop and master the material effectively? What will help students to learn better and be more successful in their interactions in education?
\end{abstract}

Keywords - education, inclusion, correctional training, learner, teacher, sociality, standard

Received: November 28, 2020. Revised: May 20, 2021. Accepted: June 12, 2021. Published: June 27, 2021.

\section{Introduction}

Tn modern times, an inclusive outlook has emerged as a 1 positive condition for the correction and development of children with disabilities. Thus, the positive pedagogical effect of the integration of children with different abilities and skills in a single educational space is noticeable.

The anthropological feature, which is an urgent requirement of modern times, requires us to develop corrective methodologies and methods based on the psychology of today's children. This condition considers the condition of children with disabilities as a normal human condition. Therefore, corrective training based on the traditional views of psychologists is being revived, and this training is beginning to gain innovative meaning.

We can see that the medical model prevailed in the society until the 1960s, both in our country and in the world. The medical model requires the elimination of diseases for people to be in society. Since the 1960s, the emergence of the Human Rights Movement has created a social model that requires persons with disabilities to participate in education and social life. (Akchamete, 2012). The social model has long been perceived as a way of engaging children with disabilities in education and assessed as "integration" (Woods 2015). However, the social model is an integrative model that requires equal education in the midst of diversity. Inclusive education is not only the adaptation of educational institutions to the needs of children with disabilities, but also requires their ability to communicate with others and to feel part of the educational process with the applied curriculum (Ainscow, 2002).
Inclusive education enables children with disabilities to receive equal education with other children (UNESCO, 1994). At the same time, it is a complex experience for those who are in early childhood. To be a part of inclusive education, it is important to understand the principle of equality in education. The main goal here is not to strive for the same result for each child, but to reveal the potential of children individually. Inclusive education is not only the inclusion of children with disabilities in the environment of other children, but also the psychological treatment of children through one form of education. This model of education should be considered as the most equitable practice in the learning process.

\section{Main Part}

The main principle in the development of inclusive approaches in education is to respect the interests of each child. For the teacher, this means that methods and practices aimed at the development of each child in the classroom must be developed and applied in pedagogical practice. The goal of inclusive education in preschools is the socialization of children with special needs by entering primary education. The main task in the implementation of inclusive education is to create a suitable school environment. They should not face obstacles when moving alone and should not lose the feeling of belonging to the school. If the school infrastructure does not meet such requirements and a student with disabilities attends a school that is insufficient for inclusive education from the point of view of infrastructure, any obstacle they face can lead them to despair and lose their sense of belonging to the school. Over the past 30 years, the number of children with disabilities has increased significantly, which in turn has become one of the factors 
making inclusive education necessary in our time. The introduction of inclusive education in preschools gives children a chance to be a part of society and improve their life prospects.

The participation of every child, especially children with disabilities in the process of pre-school education and upbringing is important. Thus, at this time, they begin to communicate with other children, they develop communicative and behavioural functions. As a result of live communication, children learn to interact with each other, which helps children with disabilities overcome developmental difficulties.

In addition to the application of special pedagogical programs in the inclusive education of children with disabilities, the creation of favourable conditions in preschool educational institutions, as well as the due construction of buildings for children with disabilities is an important factor.

The implementation of inclusive education in Azerbaijan began in 2005. According to the Resolution of the Cabinet of Ministers No. 20 dated February 3, 2005, the development program for the organization of "Education of children with special needs (with disabilities) in the Republic of Azerbaijan" was approved.

In recent years, special attention has been paid to inclusive education in our country. At present, this training method is used in more than 20 educational institutions of the republic. Although the history, stages of development and formation of inclusive education in Western countries, especially in Europe, differ in some respects, they are largely based on the same values and goals. In each of the European countries, inclusive education exists in one form or another. As Central and Eastern European countries remained under the influence of the Soviet Union until the 1990s, the values of the Soviet education system were dominated in the educational system of these countries, and in this system, the cold treatment of people with physical and intellectual disabilities kept them isolated from all spheres of public life, including education. More advanced forms of inclusive education are in developed countries such as democratic Scandinavia, Western Europe, the United States, Canada, and Australia, where liberal values are richer.

The benefits of inclusive education for children with disabilities are undeniable. Thus, children with special needs adapt to the team and integrate into society. They develop a sense of self-confidence, develop as equal members of society, and in the future their problem of employment will be eliminated. However, there are many problems in this process. At present, despite the fact that there are about 60,000 children with disabilities in Azerbaijan, only 12,000 of them have been involved in education. 1105 of them study in special schools, 2664 in special boarding schools, 7750 at home and 268 in inclusive education. And in general, parents are not interested in the participation of others in the educational process. Those involved are mainly studying in special schools and boarding schools. This type of education creates psychological trauma in children and draws their attention to their shortcomings. Therefore, such children distance themselves from society and avoid contact with others. At the same time, healthy children are surprised when they meet children with disabilities in the society because they do not communicate with them, they laugh and make fun of them. This is because they never communicate or cooperate with each other.

The lack of involvement of children in education minimizes their future integration into society, as well as their opportunities for financial independence. Even when they reach adulthood, they need the support of parents, guardians and other family members. In such a situation, society and the country as a whole lose significant human resource potential. However, this potential can be directed to future development. After all, people with disabilities can also have a unique talent. For example, Stephen Hawking is a world-renowned astrophysicist suffering from amyotrophic lateral sclerosis. This genius, who was almost completely paralyzed, wrote his name in golden letters in the history of astronomy.

The positive socio-pedagogical effect of inclusion is that, "ordinary" students gain the necessary life experience to interact with "special" students - the experience of mutual understanding, sympathy and compassion. In addition, every child from time to time has situations that reduce their academic success. The methodological potential of inclusive education allows us to support such a learner in situational learning difficulties. What is important is that, teachers have the methodological skills to use inclusive methods and techniques in a variety of situations in the learners' lives. Experience of application of inclusive education shows that, children are ready for inclusive education and are easily involved in joint activities. Unfortunately, the same cannot be said for parents. What is interesting is that parents are an obstacle to inclusive education.

Thus, the parents of other children are very aggressive towards children with disabilities, they think that they violate the educational process, and as a result, parents try to show that this problem is big. It is not often the case that a child with a disability creates problems in the classroom and at the lesson. Parents have a stereotypical approach to children with disabilities. All dissatisfaction stems from disinformation. Therefore, one of the ways to overcome this obstacle is enlightenment.

Interaction with parents is very important when organizing inclusive education. Communication and collaboration between teachers and parents can lead to more effective inclusive education. While this applies to the parents of all students, it is especially important for parents of children with disabilities. Because such parents are always with their children. They have already tried many ways to teach and educate him, and as a rule, they know very well how to approach their children. Undoubtedly, this parenting experience can be very helpful to the teacher in communicating with the child. Of course, not all parents respond to a teacher's invitation to cooperate. The ability to organize a dialogue with parents, to involve them in activities, to jointly discuss the educational needs of children in inclusive education and upbringing is one of the priorities of a modern teacher. In this context, educators must have pedagogical communication skills.

The quality of education in an inclusive class varies from teacher to teacher: "A teacher cannot engage a child in learning and ultimately cannot succeed. He also concludes that it is 
impossible to achieve any results with a child with disabilities. Because, he is not looking for the cause of his failure in himself, but in his student with disabilities. He does not think that, failure is not due to the child, but to himself. He fails to involve the child in the lesson, etc. However, there are many teachers in the classroom with children with disabilities who teach with modern teaching methods and achieve successful results. These teachers are very happy to share their experiences. In short, the reality is that persistent and competent teachers build the learning process and gain success. This is the main subject of the definition of children with disabilities. In fact, disability is not in the individual, but in society. We call this the "social model." More precisely, the search for limitations in individuals is a medical model, and the search for restrictions in the environment is a social model. In the classroom, the teacher must eliminate the reasons that hinder the individual's activities. If a teacher thinks that the limitations stem from the child, he is referring to the medical model. Conversely, if a teacher examines the reasons why he does not achieve a positive outcome in a development of student with disability and seeks ways to be effective, that teacher is referring to a social model, which is a more progressive approach.

A multidisciplinary approach is needed to meet the needs of children with disabilities. As a result of the multidisciplinary approach, it is possible to identify solutions to existing problems in a comprehensive manner, as well as to use knowledge in different disciplines in the right way in accordance with their goals. The different multidisciplinary approaches used for an effective curriculum that will help students with disabilities are: Trainings that will reveal and develop their skills; health services; (organization within the school) trainings that will serve the development of social skills; learning strategies and adaptation training to the classroom environment; approach to the environment; Thus, the role of inclusive education is very important to achieve the goal of inclusive education. The following issues should be considered when creating an inclusive education environment at schools.

Creating a positive learning environment in the classroom, an individual approach to students, promoting the right of students with disabilities to get education in general secondary schools, helping students to achieve their individual, social and academic goals;

Applying student-focused learning practices and principles by providing the necessary support for individual learning needs;

Joint learning environment: Ensuring that students with disabilities are involved in learning in the same environment and conditions through teaching methods used for the majority of students and serving to develop their skills;

Involvement of parents in such educational process, holding of trainings for them and acceptance of differences;

Informing and enlightenment of parents of students with disabilities about inclusive education;

Frequent reunification of high school students and people with disabilities, encouragement of joint cooperation, and holding group activities;
To form school culture in people with disabilities and to develop and apply procedures for following school rules.

\section{Conclusion}

Children with disabilities - is a category of learners with special characteristics that require a special education and upbringing program in addition to the educational programs adopted in connection with health conditions.

The developmental ranges of children with disabilities are extremely diverse. They can be considered as children who are practically developing normally, who are able to get out of trouble temporarily and relatively easily, or who, whom couldn't be made changes in the central nervous system. With special support, these children, along with their normally developing peers, acquire skills appropriate to their individual abilities. Although the needs of children with disabilities are similar in many ways, depending on the severity of the problems to be met, each problem may have its own characteristics.

The purpose of inclusive education is to introduce a child to society who is excluded from society for various reasons. It is possible to eliminate the "social dislocation" caused by limited health opportunities and introduce the learner to the society using specially designed education. In general, the inclusive education strategy is based on a number of positions:

To start special education for the child immediately after the initial developmental disorder is detected;

To include special sections of normal developmental peers that are not in the curriculum into the content of the child's education;

To use special methods, techniques and teaching aids (including specialized computer technologies) to ensure the implementation of "ways of solution" of training;

To individualize more than that is required for children with normal learning development;

To ensure the organization of the educational environment as a special place for children with disabilities;

To increase in maximum a field of pre-school education. Each of these responsibilities can be seen as a "growth point" for the development of advanced training programs for teachers working in an inclusive education system. In addition, these provisions may define an "innovation corridor" for the experimental activities of educational institutions.

Despite the diversity of children with disabilities, the establishment of a single standard to meet their educational needs in the learning process has had a positive impact in many countries.

The following issues related to correctional training should be reflected in the state educational standards:

Identification and taking into account the special educational needs of children with disabilities;

Implementation of individual medical, psychological and pedagogical assistance;

Ability to master the educational programs by children with disabilities;

What should be taken into account when implementing a correctional training program;

Ability of the specialists to establish a well-structured interaction. 


\section{Acknowledgment}

This work was supported by the Science Development Foundation under the President of the Republic of AzerbaijanGrant № EİF-ETL-2020-2(36)-16/16/5-M-16

\section{References}

[1] H Gürgür, A Kış, G Akçamete -"Kaynaştırma öğrencilerine sunulan bireysel destek hizmetlere ilişkin öğretmen adaylarının görüşlerinin incelenmesi” 2012

[2] A. Woods- "Inclusion of Children With Special Needs in Early Childhood Education" 2015

[3] Booth, T. and Ainscow, M - "Index for INCLUSION: Developing Learning and Participation in Schools" 2002

[4] "The Salamanca Statement and Framework for Action on Special Needs Education" 1994

[5] Papworth Trust "Disability in the United Kingdom: Facts and Figures" 2014

[6] http://az.trend.az/azerbaijan/society/1997772.html

[7] https://deti-club.ru/inklyuzivnoe-doshkolnoeobrazovanie-teoriya-i-praktika

\section{Creative Commons Attribution License 4.0 (Attribution 4.0 International, CC BY 4.0)}

This article is published under the terms of the Creative Commons Attribution License 4.0

https://creativecommons.org/licenses/by/4.0/deed.en_US 